$$
\begin{aligned}
& 322^{\prime} \\
& 6.28 \cdot 63
\end{aligned}
$$

THE ELECTRON RADIOLYSIS OF BENZENE-M-TERPHENYL AND PERDEUTEROBENZENE-M-TERPHENYL MIXTURES

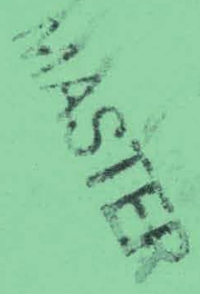

\title{
A. J. Moffat
}
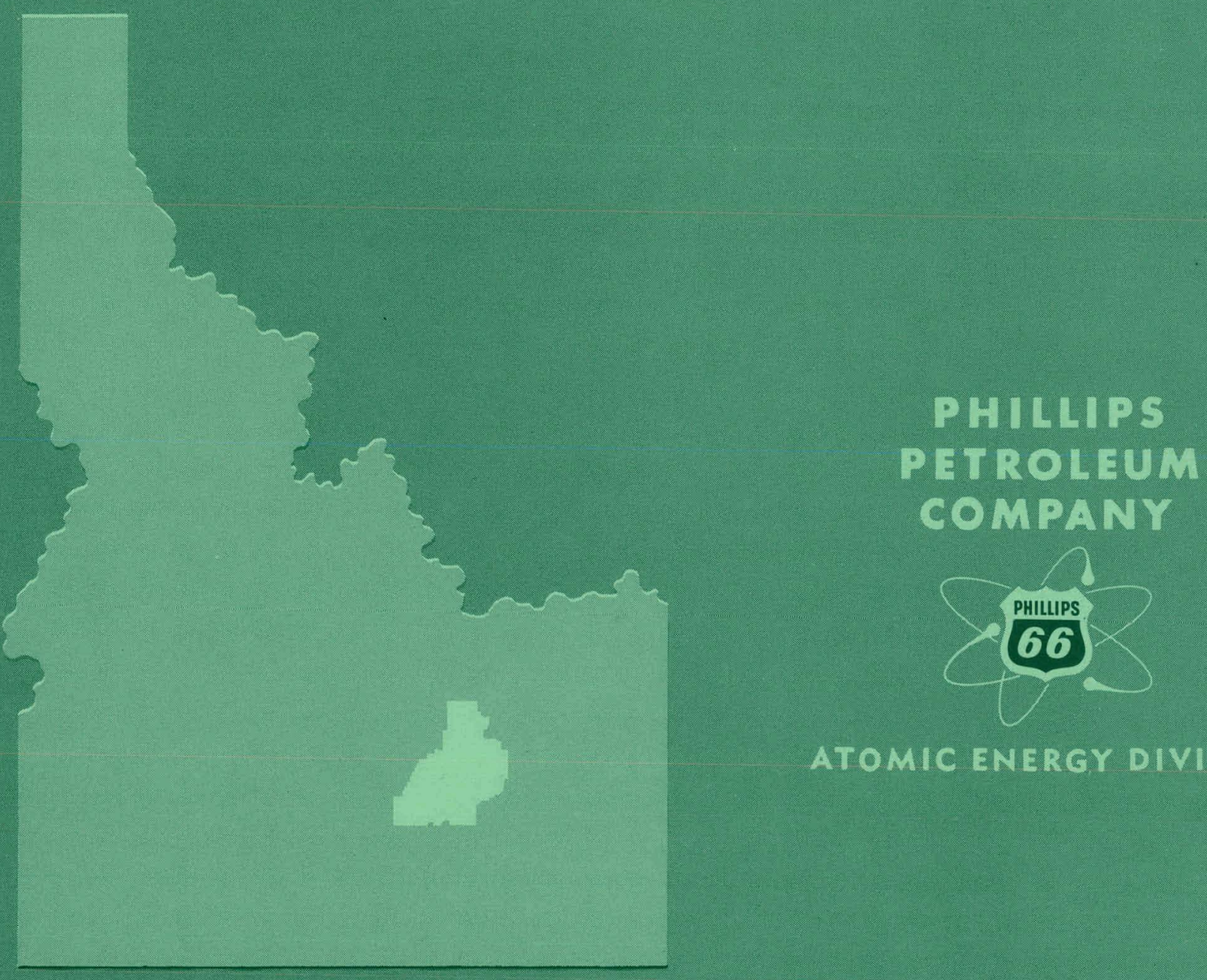

ATOMIC ENERGY DIVISION

NATIONAL REACTOR TESTING STATION US ATOMIC ENERCY COMMISSION 


\section{DISCLAIMER}

This report was prepared as an account of work sponsored by an agency of the United States Government. Neither the United States Government nor any agency Thereof, nor any of their employees, makes any warranty, express or implied, or assumes any legal liability or responsibility for the accuracy, completeness, or usefulness of any information, apparatus, product, or process disclosed, or represents that its use would not infringe privately owned rights. Reference herein to any specific commercial product, process, or service by trade name, trademark, manufacturer, or otherwise does not necessarily constitute or imply its endorsement, recommendation, or favoring by the United States Government or any agency thereof. The views and opinions of authors expressed herein do not necessarily state or reflect those of the United States Government or any agency thereof. 


\section{DISCLAIMER}

Portions of this document may be illegible in electronic image products. Images are produced from the best available original document. 
PRICE \$. 50

Available from the

Office of Technical Services

U.S. Department of Commerce

Washington 25, D. C.

\section{LEGAL NOTICE}

This report was prepared as an account of Government sponsored work. Neither the United States, nor the Commission, nor any person acting on behalf of the Commission:

A. Makes any warranty or representation, express or implied, with respect to the accuracy, completeness, or usefulness of the information contained in this report, or that the use of any information, apparatus, method, or process disclosed in this report may not infringe privately owned rights; or

B. Assumes any liabilities with respect to the use of, or for damages resulting from the use of any information, apparatus, method, or process disclosed in this report.

As used in the above, "person acting on behalf of the Commission" includes any employee or contractor of the Commission, or employee of such contractor, to the extent that such employee or contractor of the Commission, or employee of such contractor prepares, disseminates, or provides access to, any information pursuant to his employment or contract with the Commission, or his employment with such contractor. 


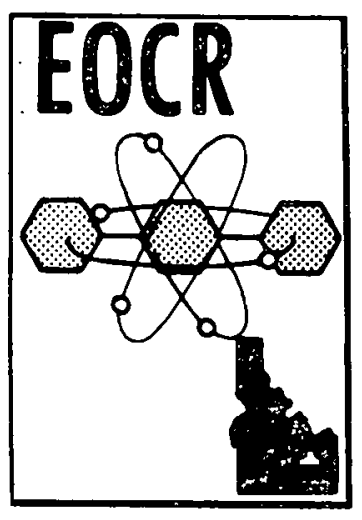

IDO-16876

AEC Research and Development Report

Reactor Technology

TID-4500 (19th Ed.)

Issued: May 1, 1963

THE ELECTRON RADIOLYSIS OF BENZENE-M-TERPHENYL

AND PERDEUTEROBENZENE-M-TERPHENYL MIXTURES

by

A. J. Moffat

PHILLIPS

PETROLEUM

COMPANY

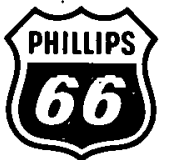

Research and Development Department

Bartlesville, Oklahoma

Contract AT(10-1)-1080

Idaho Operations Uffice

U. S. ATOMIC ENERGY COMMISSION 
THE ELECTRON RADIOLYSIS OF BENZENE-M-TERPHENYL AND PERDEUTEROBENZENE-M-TERPHENYL MIXTURES

\section{SUMMARY}

Mixtures of benzene (also perdeuterobenzene) and m-terphenyl were irradiated with $6-\mathrm{Mev}$ electrons. The primary polyphenyls products were biphenyl; $\mathrm{o}, \mathrm{m}-, \mathrm{m}, \mathrm{m}-$, and $\mathrm{m}, \mathrm{p}-q u a t e r p h e n y l s ; 1,2,3-, 1,2,4-$, and 1,3,5-triphenylbenzenes; and approximately 21 of the possible hexaphenyls. The partial reactivities of the six distinguishable m-terphenyl positions were estimated from product distributions. Initial hexaphenyl product distributions were estimated for the radiolysis of $\mathrm{m}$-terphenyl at $80^{\circ} \mathrm{C}$. 
THE ELECTRON RADIOLYSIS OF BENZENE-M-TERPHENYL AND PERDEUTEROBENZENE-M-TERPHENYL MIXTURES

\section{CONTENTS}

SUMMARY $\ldots \ldots \ldots \ldots \ldots \ldots \ldots \ldots \ldots \ldots$ ii

I INTRODUCTION $\ldots \ldots \ldots \ldots \ldots \ldots \ldots \ldots \ldots \ldots \ldots \ldots$

II. EXPERIMENTAL $\ldots \ldots \ldots \ldots \ldots \ldots \ldots \ldots \ldots \ldots \ldots$

III. RESULTS AND DISCUSSION $\ldots \ldots \ldots \ldots \ldots \ldots \ldots \ldots \ldots \ldots$

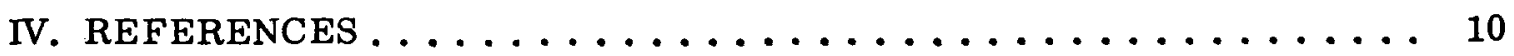

\section{TABLES}

I. Total Polyphenyl Yields from Perdeuterobenzene Polyphenyl Mixtures . . . . . . . . . . . . . . . . 7

II. Quaterphenyl Yields from the Radiolysis of BenzeneM-Terphenyl and Perdeuterobenzene-M-Terphenyl Mixtures $\ldots \ldots 7$

III. Reactive Species and Scavenging Probabilities of Irradiated M-Terphenyl; Partial Reaction Rates . . . . . . . . 8

IV. Predicted Initial Hexaphenyl Product Yields froin the Irradiation of M-Terphenyl $\ldots \ldots \ldots \ldots \ldots \ldots 10$ 


\section{THE ELECTRON RADIOLYSIS OF BENZENE-M-TERPHENYL}

AND PERDEUTEROBENZENE-M-TERPHENYL MIXTURES

\section{INTRODUCTION}

A model was proposed by Hutchinson et al for separating the relative reactivities of the three distinguishable positions of biphenyl. The relative positional reactivities were determined both for activated species formation and for scavenging reactions. A similar approach was used by the author which involved studying benzene-biphenyl mixtures ${ }^{[1]}$.

The purpose of this research was to determine the relative reactivities of the six m-terphenyl positions with respect to activated species formation and scavenging reactions.

\section{EXPERIMENTAL}

The benzene (also perdeuterobenzene)-m-terphenyl mixtures were ir radiated under the Linac at $80^{\circ} \mathrm{C}$ using $6-\mathrm{Mev}$ (average) electrons. The irradiation time varied from two to three hours. Approximately one to two percent of the reactants were converted to product.

The m-terphenyl was purified as described previously [2]. Perdeuterobenzene of 99.5 percent isotopic purity was obtained from Volk Radio Chemical Co.

Benzene-m-terphenyl mixtures were placed in glass ampoules and degassed by a series of melt, freeze, and evacuation steps at $0.05 \mathrm{~mm}$. The resultant samples were sealed and irradiated as described above.

The analyses were completed using gas-solid chromatography [3, 4]. Each irradiated sample of unknown composition was compared with known samples to obtain appropriate peak area correction factors. Two different types of columns were used. A five-foot, 20 percent $\mathrm{LiCl}$ (on firebrick) column was used to obtain total polyphenyl product yields and to separate 1,2,3-triphenylbenzene from pterphenyl impurity. Five-foot columns packed with 35 to 50 percent $\mathrm{CaCl}_{2}$ on firebrick were necessary to resolve the 1,3,5-triphenylbenzene and $\mathrm{m}, \mathrm{m}$ quaterphenyl peaks. 


\section{RESULTS AND DISCUSSION}

The irradiation of pure m-terphenyl would be expected to produce as principal polyphenyl products 21 possible hexaphenyls. The first expected event should be the generation of a reactive species:

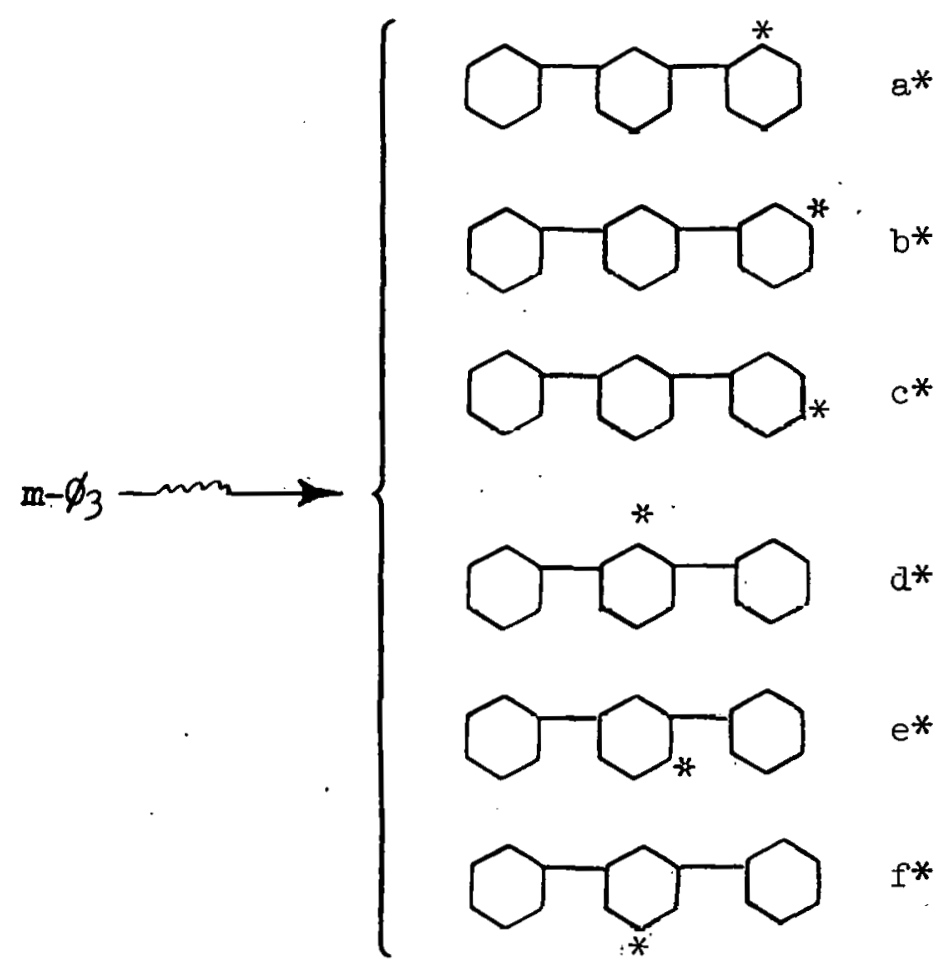

Each of the reactive species, $a^{*}$ for example, reacts with or is scavenged by $m$-terphenyl to produce hexaphenyls of the type noted in Equation (2).

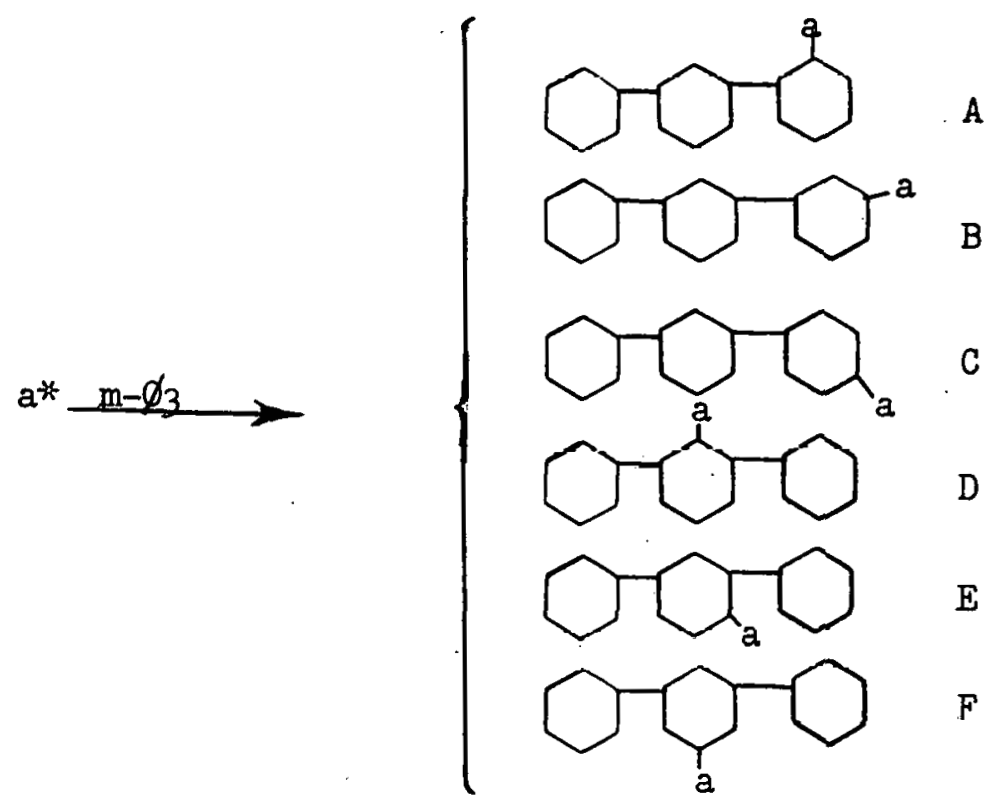


Let $\underline{a}, \underline{b}, \underline{c}, \underline{d}, \underline{e}$, and $\underline{f}$ be the mole fraction yields of the $a^{*}, b^{*}$, etc, reactive species in Equation (1) such that:

$$
a+b+c+d+e+f=1.00
$$

A reactive species may be scavenged by any of the six distinguishable positions on $\mathrm{m}$-terphenyl. Let $\underline{\mathrm{A}}, \underline{\mathrm{B}}, \underline{\mathrm{C}}, \underline{\mathrm{D}}, \underline{\mathrm{E}}$, and $\underline{\mathrm{F}}$ be the average probability that a given reactive species will be scavenged by each of the positions (respectively) noted in Fruiation (2). Thus,

$$
A+B+C+D+E+F=1.00
$$

A series of equations can be set up to describe the relative yields of each of the 21 hexaphenyl products in terms of reactive species and scavenging probabilities. For example, the mole fraction yield of $\mathrm{m}, \mathrm{o}, \mathrm{m}, \mathrm{m}$-hexaphenyl should be

$$
\mathrm{Ym}, \mathrm{o}, \mathrm{m}, \mathrm{m}-\emptyset_{6}=\mathrm{aB}+\mathrm{bA}
$$

To evaluate these reactive species and scavenging probabilities, the relative yields of at least 11 of the hexaphenyl products must be determined. This is not analytically possible at this time.

However, the relative reactivities of the six m-terphenyl positions can be determined by studying the radiolysis of benzene-m-terphenyl and perdeuterobenzene-m-terphenyl mixtures. The basic mechanism appears to be

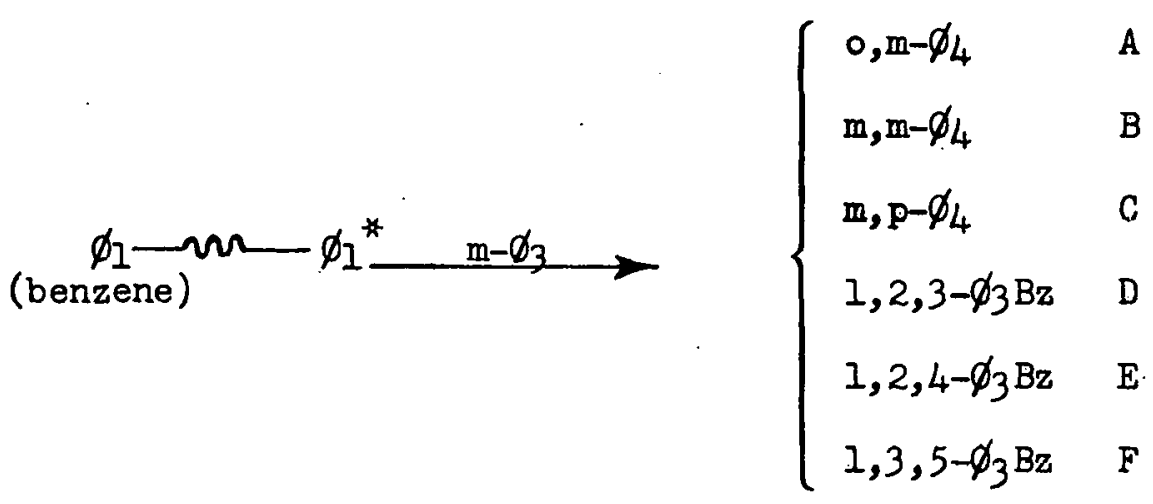

where $\underline{A},-\underline{B}, \underline{C}, \underline{D}, \underline{E}$, and $\underline{F}$ should be equivalent to those listed in Equations (2) and (4). Similarly, 


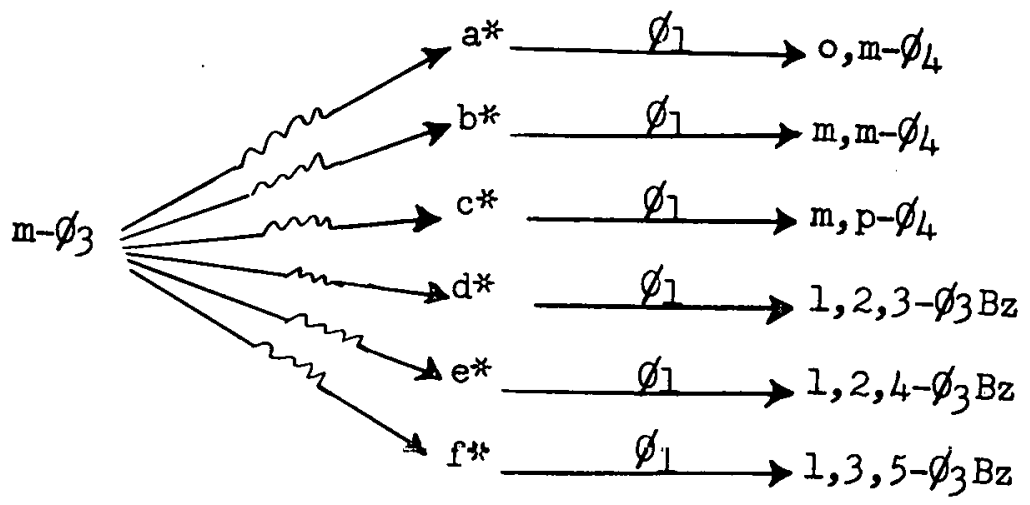

Experimentally, using GSC analyses, the biphenyl yield, the individual quaterphenyl yields, and the total hexaphenyl yield can be measured and expressed on a mole fraction basis:

$$
\mathrm{Y} \emptyset_{2}+\sum_{1}^{6} \mathrm{Y} \emptyset_{4}+\sum_{1}^{21} \mathrm{Y} \emptyset_{6}=1.00
$$

For the perdeuterobenzene and m-terphenyl mixtures, the initial polyphenyl product yields may be expressed as:

$$
\mathrm{Y}^{\prime} \emptyset_{2}+\sum_{1}^{6} \mathrm{Y}^{\prime} \emptyset_{4}+\sum_{1}^{21} \mathrm{Y}^{\prime} \emptyset_{6}=1.00
$$

Following a procedure described recently ${ }^{[5]}$, the reactive species and scavenging probabilities were related to initial polyphenyl product yields from irradiated benzene-m-terphenyl mixtures by:

$$
\begin{gathered}
\mathrm{Y} \emptyset_{2}=\mathrm{nN} \\
\sum_{1}^{6} \mathrm{Y} \emptyset_{4}=\mathrm{n}(1-\mathrm{N})+(1-\mathrm{n}) \mathrm{N} \\
\sum_{1}^{21} \mathrm{Y} \emptyset_{6}=(1-\mathrm{n})(1-\mathrm{N})
\end{gathered}
$$

Similarly, Equations (13), (14), and (15) were derived for the perdeuterobenzenem-terphenyl system. 


$$
\begin{gathered}
\mathrm{Y} \emptyset_{2}=\mathrm{nM} \\
\sum_{1}^{6} \mathrm{Y}^{\prime} \emptyset_{4}=\mathrm{m}(1-\mathrm{M})+(1-\mathrm{m}) \mathrm{M} \\
\sum_{1}^{21} \mathrm{Y}^{\prime} \emptyset_{6}=(1-\mathrm{m})(1-\mathrm{M})
\end{gathered}
$$

Where $\underline{n}$ and $\underline{m}$ refer to the probability of forming a $\emptyset_{1}{ }^{*}$ species from benzene and perdeuterobenzene, respectively. $\underline{N}$ and $\underline{M}$ refer to the scavenging probabilities of benzene and perdeuterobenzene, respectively.

Using the relationships noted in Equations (3), (4), (6), (7), (10), (11), and (12), the yield of o,m-quaterphenyl from the benzene-m-terphenyl system should be:

$$
\mathrm{Yo}, \mathrm{m}-\emptyset_{4}=\mathrm{n}(1-\mathrm{N}) \mathrm{A}+(1-\mathrm{n}) \mathrm{aN}
$$

The two terms in Equation (16) arise from the two ways in which $0, m-\emptyset_{4}$ can be formed. The first term gives the mole fraction yield of o,m-quaterphenyl which should result from benzene activated species attacking or being scavenged by the ortho position of m-terphenyl:

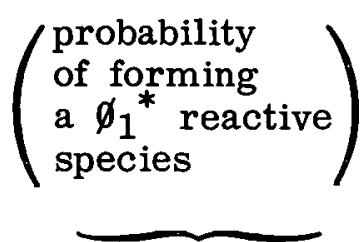

n

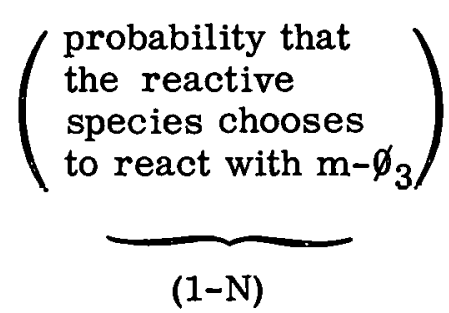

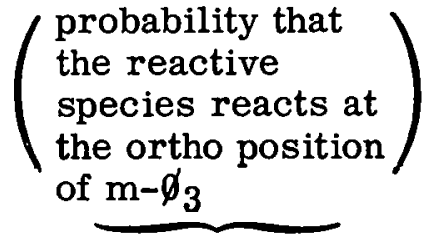

A

The second term in Equation (16) gives the mole fraction yield of $0, \mathrm{~m}-\emptyset_{4}$ which should result from $m$-terphenyl molecules activated in the ortho position ( $a^{*}$ ) attacking or being scavenged by benzene:

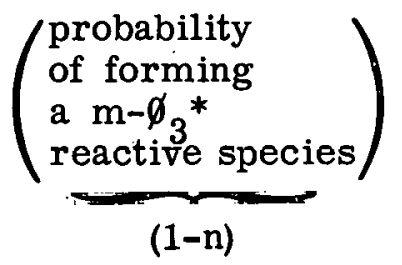

$(1-n)$

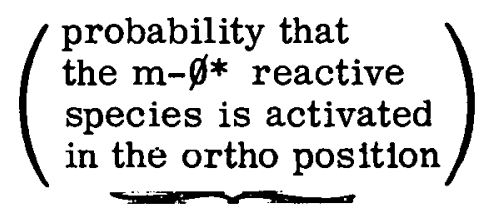

a

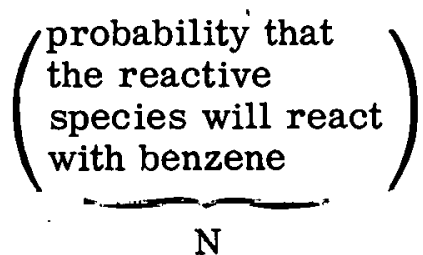


Similarly, the $o, m-q u a t e r p h e n y l$ yield from the perdeuterobenzene-m-terphenyl system should be:

$$
\mathrm{Y}^{\prime} \mathrm{o}, \mathrm{m}-\emptyset_{4}=\mathrm{m}(1-\mathrm{M}) \mathrm{A}+(1-\mathrm{m}) \mathrm{AM}
$$

By substituting the values of $\underline{n}, \underline{N}, \underline{m}$, and $\underline{M}$ [calculated from Equations (10) to (15)] into Equations (16) and (17), a and $\underline{A}$ can be evaluated. Similarly, the following sets of simultaneous equations may be solved to yield: b, B, c, C, d, D, e, F., $f$, and $F$.

$$
\begin{aligned}
& \mathrm{Ym}, \mathrm{m}-\emptyset_{4}=\mathrm{n}(1-\mathrm{N}) \mathrm{B}+(1-\mathrm{n}) \mathrm{Nb} \\
& \mathrm{Y}^{\prime} \mathrm{m}, \mathrm{m}-\emptyset_{4}=\mathrm{m}(1-\mathrm{M}) \mathrm{B}+(1-\mathrm{m}) \mathrm{Mb} \\
& \mathrm{Ym}, \mathrm{p}-\emptyset_{4}=\mathrm{n}(1-\mathrm{N}) \mathrm{C}+(1-\mathrm{n}) \mathrm{Nc} \\
& \mathrm{Y}^{\prime} \mathrm{m}, \mathrm{p}-\emptyset_{4}=\mathrm{m}(1-\mathrm{M}) \mathrm{C}+(1-\mathrm{m}) \mathrm{Mc} \\
& \mathrm{Y} 1,2,3-\emptyset_{3} \mathrm{Bz}=\mathrm{n}(1-\mathrm{N}) \mathrm{D}+(1-\mathrm{n}) \mathrm{Nd} \\
& \mathrm{Y}^{\prime} 1,2,3-\emptyset_{3} \mathrm{Bz}=\mathrm{m}(1-\mathrm{M}) \mathrm{D}+(1-\mathrm{m}) \mathrm{Md} \\
& \mathrm{Y} 1,2,4-\emptyset_{3} \mathrm{Bz}=\mathrm{n}(1-\mathrm{N}) \mathrm{E}+(1-\mathrm{n}) \mathrm{Ne} \\
& \mathrm{Y}^{\prime} 1,2,4-\emptyset_{3} \mathrm{Bz}=\mathrm{m}(1-\mathrm{M}) \mathrm{E}+(1-\mathrm{m}) \mathrm{Me} \\
& \mathrm{Y} 1,3,5-\emptyset_{3} \mathrm{Bz}=\mathrm{n}(1-\mathrm{N}) \mathrm{F}+(1-\mathrm{n}) \mathrm{Nf} \\
& \mathrm{Y}^{\prime} \cdot 1,3,5-\emptyset_{3} \mathrm{Bz}=\mathrm{m}(1-\mathrm{M}) \mathrm{F}+(1-\mathrm{m}) \mathrm{Mf}
\end{aligned}
$$

Since each of the systems studied had somewhat different benzene/mterphenyl and perdeuterobenzene/m-terphenyl mole ratios, the following relationships [5] were used to convert $\mathrm{n}_{1.0}, \mathrm{~N}_{1.0}$ and also $\mathrm{m}_{1.0}$ and $\mathrm{M}_{1.0}$ to the appropriate activated species and scavenging probabilities.

$$
\begin{aligned}
& \left(\frac{\mathrm{n}}{1-\mathrm{n}}\right)=\left(\frac{\mathrm{n}_{1.0}}{1-\mathrm{n}_{1.0}}\right)\left(\frac{\emptyset_{1}}{\mathrm{~m}-\emptyset_{3}}\right) \\
& \left(\frac{\mathrm{N}}{1-\mathrm{N}}\right)=\left(\frac{\mathrm{N}_{1.0}}{1-\mathrm{N}_{1.0}}\right)\left(\frac{\emptyset_{1}}{\mathrm{~m}-\emptyset_{3}}\right)
\end{aligned}
$$

$\mathrm{N}_{1.0}, \mathrm{n}_{1.0}, \mathrm{M}_{1.0}$, and $\mathrm{m}_{1.0}$ refer to equal molar benzene and $\mathrm{m}$-terphenyl mixtures.

Table I lists duplicate analyses which were made to determine average $\mathrm{m}_{1.0}$ and $\mathrm{M}_{1.0}$ values. Average values for $\mathrm{n}_{1.0}$ and $\mathrm{N}_{1.0}$ were obtained from a previous report by the author [5].

Using the mole fraction quaterphenyl yields in Table II and the average $\mathrm{n}_{1.0}, \mathrm{~N}_{1.0}, \mathrm{~m}_{1.0}$, and $\mathrm{M}_{1.0}$ values listed in Table $\mathrm{I}$, the reactive species and scavenging probabilities for each of the sixdistinguishable m-terphenyl positions 
TABLE I

TOTAL POLYPHENYL YIELDS FROM PERDEUTEROBENZENE POLYPHENYL MIXIURES

\begin{tabular}{|c|c|c|}
\hline$\left(\mathrm{C}_{6} \mathrm{D}_{6} / \mathrm{m}-\phi_{3}\right)$ & 1.266 & 1.403 \\
\hline$\phi_{2}$ & 0.060 & 0.063 \\
\hline$\sum_{I}^{6} \phi_{4}$ & 0.382 & 0.399 \\
\hline$\sum_{1}^{21} \phi_{6}$ & 0.558 & 0.538 \\
\hline $\mathrm{m}$ & 0.305 & 0.339 \\
\hline M & 0.197 & 0.186 \\
\hline $\mathrm{m}_{1.0}$ & 0.257 & 0.268 \\
\hline$M_{1.0}$ & 0.162 & 0.140 \\
\hline \multicolumn{3}{|c|}{$\begin{array}{l}\text { The values of } m_{1} .0 \text { and } M_{1} .0 \text { which were used in all the calculations are } \\
0.263 \text { and } 0.151 \text {, respectively. The average } n_{1.0} \text { and } N_{1} .0 \text { values which } \\
\text { were used are } 0.446 \text { and } 0.136 \text {, respectively. }\end{array}$} \\
\hline
\end{tabular}

\section{TABLE II}

QUATERPHENYL YIELDS FROM THE RADIOLYSIS OF BENZENE-M-TERPHENYL AND PERDEUTEROBENZENE-M-TERPHENYL MIXTURES

\begin{tabular}{|c|c|c|c|c|c|c|}
\hline & $\begin{array}{c}14 \mathrm{~B} \\
1\end{array}$ & $\begin{array}{c}15 \mathrm{~A} \\
2 \\
\end{array}$ & $\begin{array}{c}150 \\
3\end{array}$ & $\begin{array}{c}86 \mathrm{~B} \\
4 \\
\end{array}$ & $\begin{array}{c}15 \mathrm{~B} \\
5 \\
\end{array}$ & $\begin{array}{c}15 \mathrm{C} \\
6 \\
\end{array}$ \\
\hline$\left(\mathrm{C}_{6} \mathrm{H}_{5} / \mathrm{m}-\phi_{3}\right)$ & - & - & - & 1.342 & 1.396 & 1.303 \\
\hline$\left(\mathrm{C}_{6} \mathrm{D}_{6} / \mathrm{m}-\phi_{3}\right)$ & 1.252 & 1.266 & 1.403 & - & - & - \\
\hline $\begin{array}{l}1,2,3-\phi_{3} \mathrm{Bz} \\
0, \mathrm{~m}-\phi_{4} \\
1,2,4-\phi_{3} \mathrm{Bz} \\
\mathrm{m}, \mathrm{m}-\phi_{4} \\
1,3,5-\phi_{3} \mathrm{Bz} \\
\mathrm{m}, \mathrm{p}-\phi_{4}\end{array}$ & $\begin{array}{l}0.0254 \\
0.0865 \\
0.0768 \\
0.0856 \\
0.0179 \\
0.0907\end{array}$ & $\begin{array}{l}0.0240 \\
0.0818 \\
0.0804 \\
0.0883 \\
0.0176 \\
0.0824\end{array}$ & $\begin{array}{l}0.0279 \\
0.0855 \\
0.0823 \\
0.0958 \\
0.0192 \\
0.0956\end{array}$ & $\begin{array}{l}0.0242 \\
0.1063 \\
0.1131 \\
0.1017 \\
0.0217 \\
0.1256\end{array}$ & $\begin{array}{l}0.0309 \\
0.1111 \\
0.1164 \\
0.1093 \\
0.0236 \\
0.1136\end{array}$ & $\begin{array}{l}0.0403 \\
0.1081 \\
0.1091 \\
0.1017 \\
0.0208 \\
0.1148\end{array}$ \\
\hline$\sum_{1}^{1} Y \phi_{4}$ & 0.3829 & 0.3745 & 0.4063 & 0.4920 & .5049 & .4948 \\
\hline
\end{tabular}


were determined. These results, listed in Table III, were determined by comparing each of the perdeuterobenzene samples with each of the three benzene samples.

\section{TABLE III}

REACTTVE SPECIES AND SCAVENGING PROBABILITIES

OF IRRADIATED M-TERPHENYL; PARTIAL REACTION RATES

\begin{tabular}{|c|c|c|c|c|}
\hline $\begin{array}{l}a \\
b \\
c \\
d \\
e \\
f\end{array}$ & $\begin{array}{l}0.219 \pm 0.029 * \\
0.309 \pm 0.034 \\
0.207 \pm 0.060 \\
0.074 \pm 0.049 \\
0.136 \pm 0.031 \\
0.056 \pm 0.007\end{array}$ & $\cdot$ & $\begin{array}{l}\mathrm{A} \\
\mathrm{B} \\
\mathrm{C} \\
\mathrm{D} \\
\mathrm{E} \\
\mathrm{F}\end{array}$ & $\begin{array}{l}0.218 \pm 0.008 \\
0.186 \pm 0.015 \\
0.244 \pm 0.029 \\
0.061 \pm 0.029 \\
0.249 \pm 0.012 \\
0.041 \pm 0.014\end{array}$ \\
\hline $\begin{array}{l}r_{a} \\
r_{b} \\
r_{c} \\
r_{d} \\
r_{e} \\
r_{f}\end{array}$ & $\begin{array}{l}0.71 \\
1.00 \\
1.34 \\
0.96 \\
0.88 \\
0.72\end{array}$ & & $\begin{array}{l}\mathrm{k}_{\mathrm{A}} \\
\mathrm{k}_{\mathrm{B}} \\
\mathrm{k}_{\mathrm{C}} \\
\mathrm{k}_{\mathrm{D}} \\
\mathrm{k}_{\mathrm{E}} \\
\mathrm{k}_{\mathrm{F}}\end{array}$ & $\begin{array}{l}1.17 \\
1.00 \\
2.62 \\
1.31 \\
2.68 \\
0.88\end{array}$ \\
\hline & tandard deviation. & & & \\
\hline
\end{tabular}

Partial reaction rates were computed using the following:

$$
\begin{array}{ll}
\mathbf{r}_{\mathrm{a}}=\frac{\mathrm{a}}{\mathrm{b}} & \mathrm{r}_{\mathrm{d}}=\frac{4 \mathrm{~d}}{\mathrm{~b}} \\
\mathbf{r}_{\mathrm{b}}=\frac{\mathrm{b}}{\mathrm{b}} & \mathrm{r}_{\mathrm{e}}=\frac{2 \mathrm{e}}{\mathrm{b}} \\
\mathbf{r}_{\mathrm{c}}=\frac{2 \mathrm{c}}{\mathrm{b}} & \mathrm{r}_{\mathrm{f}}=\frac{4 \mathrm{f}}{\mathrm{b}} \\
\mathrm{k}_{\mathrm{A}}=\frac{\mathrm{A}}{\mathrm{B}} & \mathrm{k}_{\mathrm{D}}=\frac{4 \mathrm{D}}{\mathrm{B}} \\
\mathrm{k}_{\mathrm{B}}=\frac{\mathrm{B}}{\mathrm{B}} & \mathrm{k}_{\mathrm{E}}=\frac{2 \mathrm{E}}{\mathrm{B}} \\
\mathrm{k}_{\mathrm{C}}=\frac{2 \mathrm{C}}{\mathrm{B}} & \mathrm{k}_{\mathrm{F}}=\frac{4 \mathrm{~F}}{\mathrm{~B}}
\end{array}
$$

Thus, each of the individual positions may be compared to the meta position with regard to reactive species formation and scavenging reaction. These partial reaction rates are listed in Table III. 
The values calculated for A, B, C, etc, represent the probability that an activated benzene species will be scavenged by each of the positions; or these values measure the relative reactivity of each of the $m$-terphenyl positions with respect to attack by an activated benzene species. If one assumes that other activated species such as $a^{*}, b^{*}$, etc, attack the m-terphenyl molecule with the same relative frequency as the benzene reactive species, then the data in Table III can be used to predict the initial hexaphenyl product distribution obtained from the irradiation of pure $m$-terphenyl.

Using Equation (5) and similar equations such as:

$$
\begin{aligned}
& \text { Ym,m,m,m- } \emptyset_{6}=\mathrm{bc}+\mathrm{cB} \\
& \mathrm{Ym}, \mathrm{m}, \mathrm{m}-\emptyset_{6}=\mathrm{bB} \\
& \mathrm{Ym}, \mathrm{o}, \mathrm{p}, \mathrm{m}-\emptyset_{6}=\mathrm{aC}+\mathrm{cA} \\
& \mathrm{Ym}, \mathrm{o}, \mathrm{o}, \mathrm{m}-\emptyset_{6}=\mathrm{aA} \\
& \mathrm{Ym}, \mathrm{p}, \mathrm{p}, \mathrm{m}-\emptyset_{6}=\mathrm{cC} \quad \text { etc }
\end{aligned}
$$

The relative hexaphenyl yields from pure $\mathrm{m}$-terphenyl were calculated and are listed in Table IV.

The second column in Table IV represents Hutchinson's predicted hexaphenyl distribution (for $\mathrm{m}$-terphenyl radiolysis at $80^{\circ} \mathrm{C}$ ). These predictions were based upon biphenyl partial rate factors (1) and the principle of additivity ${ }^{[6]}$.

For example, it was assumed that:

$$
\begin{aligned}
\mathrm{k}_{\mathrm{D}}=\mathrm{k}_{\mathrm{A}}^{2} & \mathbf{r}_{\mathrm{d}}=\mathrm{r}_{\mathrm{a}}^{2} \\
\mathrm{k}_{\mathrm{E}}=\mathrm{k}_{\mathrm{A}}^{\mathrm{kC}} & \mathrm{r}_{\mathrm{e}}=\mathrm{r}_{\mathrm{a}} \mathrm{r}_{\mathrm{c}} \\
\mathrm{k}_{\mathrm{F}}=\mathrm{k}_{\mathrm{B}}^{2} & \mathrm{r}_{\mathrm{f}}=\mathrm{r}_{\mathrm{B}}^{2}
\end{aligned}
$$

where $k_{A}$, $k_{B}$, and $k_{C}$ refer to the scavenging partial rate factors of the ortho, meta, and para position of biphenyl, respectively; and $k_{D}, k_{E}$, and $k_{F}$ are the predicted partial rate factors for the three distinguishable positions on the center ring of $m$-terphenyl. The $k_{A}, k_{B}$, and $k_{C}$ biphenyl values are assumed to be the same for m-terphenyl. The agreement between the two predicted hexaphenyl distributions in Table IV indicates that the additivity principle may be reasonably accurate for product predictions in complicated polyphenyl radiolytic studies. 
PREDICTED INITIAL HEXAPHENYL PRODUCT YIELDS FROM THE IRRADIATION OF M-TERPHENYL

\begin{tabular}{|c|c|c|c|}
\hline & & From $m-\Phi_{3}$ data & From $\phi_{2}$ data \\
\hline $\begin{array}{l}1 . \\
2 . \\
3 . \\
4 . \\
5 . \\
6 . \\
7 . \\
8 . \\
9 . \\
10 . \\
11 . \\
12 . \\
13 . \\
14 . \\
15 . \\
16 . \\
17 . \\
18 . \\
19 . \\
20 . \\
21 .\end{array}$ & $\begin{array}{l}\text { m, p,m,m-hexaphenyl } \\
\text { m,o,m,m-hexaphenyl } \\
\text { 2,4-diphenyl-3'-(3-xenyl)-biphenyl } \\
\text { m,o,p,m-hexaphenyl } \\
\text { 2,4-diphenyl-4'-(3-xenyl)-blphenyl } \\
\text { 2,4-diphenyl-2'-(3-xenyl)-biphenyl } \\
\text { m,m,m,m-hexaphenyl } \\
\text { m,p,p,m-hexaphenyl } \\
\text { m,o,o,m-hexaphenyl } \\
\text { 2,2',4,4'-tetraphenyl-biphenyl } \\
\text { 2,6-diphenyl-3'-(3-xenyl)-biphenyl } \\
\text { 2,6-diphenyl-4'-(3-xenyl)-biphenyl } \\
\text { 2,6-diphenyl-2'-(3-xenyl)-biphenyl } \\
\text { 2,6,2',4'-tetraphenyl-biphenyl } \\
\text { 3,5-diphenyl-3'-(3-xenyl)-biphenyl } \\
\text { 3,5-diphenyl-4'-(3-xenyl)-biphenyl } \\
\text { 3,5-diphenyl-2'-(3-xenyl)-biphenyl } \\
\text { 2,4,3',5'-tetraphenyl-biphenyl } \\
\text { 2,6,3',5'-tetraphenyl-biphenyl } \\
\text { 2,6,2',6'-tetraphenyl-biphenyl } \\
\text { 3,5,3',5'-tetraphenyl-biphenyl }\end{array}$ & $\begin{array}{r}11.4 \\
10.7 \\
10.2 \\
9.9 \\
8.5 \\
8.4 \\
5.8 \\
5.1 \\
4.6 \\
3.4 \\
3.3 \\
3.1 \\
3.0 \\
2.7 \\
2.3 \\
2.2 \\
2.1 \\
2.0 \\
0.6 \\
0.5 \\
0.2\end{array}$ & $\begin{array}{r}9.1 \\
10.9 \\
11.7 \\
9.0 \\
7.1 \\
11.0 \\
4.8 \\
3.1 \\
5.8 \\
3.8 \\
3.3 \\
2.4 \\
3.3 \\
2.7 \\
2.4 \\
2.3 \\
2.7 \\
2.9 \\
0.8 \\
0.4 \\
0.3\end{array}$ \\
\hline
\end{tabular}

Improved analytical procedure and known hexaphenyls for reference compounds would allow a direct and complete solution of the m-terphenyl problem. This work covers just one aspect of the extremely complicated radiation chemistry of polyphenyls. However, the approach can be expanded to include the formation and fate of hydroaromatics, the production of hydrogen and gaseous hydrocarbons, and secondary product formation when the data become available.

\section{IV, REFERENCES}

1. A. J. Moffat, The Electron Radiolysis of Benzene-Biphenyl Mixtures (to be published).

2. Organic Reactor Technology Quarterly Report, 2nd Qtr 1962, IDO-16807 (1962). 
3. A. J. Moffat, P. W. Solomon, The Gas-Solid Chromatographic Separation of Polyphenyls on Lithium Chloride - Firebrick, IDO-16732 (November 10, 1961).

4. P. W. Solomon, Polyphenyl Analysis (to be published).

5. A. J. Moffat, "Radiolysis of Benzene-Polyphenyl Mixtures", Proceedings of the Third Conference on Nuclear Reactor Chemistry, Gatlinburg, Tennessee, October 9-11, 1962 (to be published).

6. D. R. Augood, G. H. Williams, "Homolytic Aromatic Arylation”, Chem. Rev., 57, pp 123-90 (1957). 


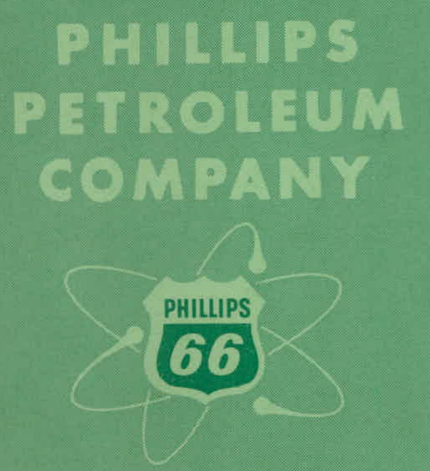

ATOMIC ENERGY DIVISION 